Seyahat ve Otel İşletmeciliği Dergisi/

Journal of Travel and Hospitality Business

Cilt/Nol:18(2),Yıl/ Year: 2021, ss/pp: 399-420.

Gönderim Tarihi/ Received: 01.05.2021

Kabul Tarihi /Accepted: 21.05 .2021

DOI: $10.24010 /$ soid. 886339

Araştırma Makalesi/ Research Article

\title{
Trade-Union Trust Perception in the Lodging Sector: A Research on Sector Stakeholders*
}

\section{Otelcilik Sektöründe Sendikal Güven Algısı: Sektör Paydaşları Üzerine Bir Araştırma}

\author{
Dr. Öğr. Üyesi Recep YILDIRGAN \\ Sakarya Uygulamalı Bilimler Üniversitesi \\ Sapanca Turizm MYO \\ E-posta: recepy@subu.edu.tr
}

\author{
Prof.Dr. Orhan BATMAN \\ Sakarya Uygulamalı Bilimler Üniversitesi \\ Turizm Fakültesi, Sakarya, Türkiye \\ E-posta: obatman@subu.edu.tr
}

\section{Abstract}

This study is reviewed from the point of confidence and insecurity dimensions of Turkey's unorganized hospitality sector unionization trends. Research data were obtained both quantitatively and qualitatively. Quantitative data were collected from 805 hotel employees working in Istanbul and Antalya. Qualitative data were collected by conducting in-depth interviews with professional hotel managers and union managers. The research results revealed that hotel employees have a lack of trust towards unions and trade unionists. According to the union executives, the low level of union organization in this line of work was mostly due to the sector capitalists' attitudes. Besides, as per the sector and professional hotel managers' employers, it has been discovered that if the existing union structure changes, they may lean towards union organizing.

Key Words: Union, Trade Union Trust, Tourism, Hotel, Worker, Employer.

\section{Öz}

Bu çalışma Türkiye otelcilik sektöründeki sendikalaşma eğilimini sendikalara olan güven ve güvensizlik boyutları açısından ele almaktadır. Yaşanan sorunların temelinde sektörün kendine özgü koşulları, istihdamın yapısı, işverenlerin örgütlenmeye yaklaşımları, turizm çalışanlarının sendikalı olup/olmaması etken faktörler olarak gösterilmektedir. Konunun sektörün paydaşları olan çalışanlar, profesyonel otel yöneticileri ile sendika yöneticileri açısından değerlendirilmesi amaçlanmaktadır. Araştırma verileri hem nicel hem de nitel olarak elde edilmiştir. İstanbul ve Antalya'da çalışan 805 otel çalışanından anket ile nicel veriler toplanmıştır. Profesyonel otel yöneticileri ve sendika yöneticileri ile derinlemesine mülakatlar yapılarak nitel veriler elde edilmiştir. Araştırma sonuçları otel çalışanlarının sendika ve sendikacılara yönelik güven eksikliklerinin olduğunu ortaya koymuştur. Sendika yöneticileri bu iş kolundaki düşük sendikal örgütlenmenin daha çok sektör sermayedarlarının tutumlarından kaynaklandığını ileri sürmüşlerdir. Sektör işverenleri ve profesyonel otel yöneticilerine göre ise mevcut sendikal yapının değişmesi durumunda sendikal örgütlenmeye sıcak bakabilecekleri görüşü tespit edilmiştir.

Anahtar Kelimeler: Sendika, Sendikal Güven, Turizm, Otel, İşçi, İşveren.

*Bu çalışma, Recep YILDIRGAN'ın Sakarya Uygulamalı Bilimler Üniversitesi Lisansüstü Eğitim Enstitüsünde kabul edilmiş olan 'Türk Konaklama Sektöründe Sendikalaşma Üzerine Bir Araştırma' adlı doktora tezimden üretilmiştir 


\section{Introduction}

Trade Unions' contribution to business life in a labor-intensive industry like tourism cannot be denied. Yet, both around the world and Turkey's tourism industry are challenging to speak of a massive impact on trade union relations. The labor-intensive nature of tourism addresses the human factor much more significant in this line of business. Still, the tourism business line varies from many professions by various working conditions due to unique features. For instance, the tourism industry displays an extraordinary feature in the sense of working hours all over the world (Tüzünkan, 2015: 246). Tourism employees, one of the most important actors in tourism, which has turned into a mass movement in the world since the 1950s and in Turkey since the 1980s and has become an industry with increased socio-economic weight, could not get their share from this quantitative and qualitative development. It can be easily observed that there is a low rate of union organization among tourism workers. The existing organization does not have enough power to provide positive results in favor of employees by looking at the general lines of the current picture (Tekin et al. 2015: 172). It is observed that de-unionization is increasing as a general trend around the world. The most crucial reason for the low rate of unionization in the services industry, which includes tourism, is that, contrary to the industrial worker's collective behavior, the individualist behavior prevails in this sector. While the idea of solidarity and unity of destiny is dominant among those working in the industrial sector, such an opinion does not develop between those working in the service sector due to the job (Kocabaş, 2004: 25). According to the January 2020 data of the Ministry of Family, Labor, and Social Services, the rate of unionization in the Hospitality and Entertainment Affairs business line in our country is $3.9 \%$. This ratio ensures that this business line takes the last place in the unionization ranking among the others. If unregistered workers are also taken into account, it is evident that the rate of non-unionism in this industry will be much higher. The seasonality of the tourism industry, its disadvantages in terms of job security, subcontracting, the option of employing part-time workers, too much ideological attitude of the unions, the threat of dismissal by the workers who are union members, the employers and managers seeing the union as a threat can be considered as the principal obstacles to union organization in this field (MoFLSS, 2019).

This study examines the tendency of unionization in Turkey's lodging sector from the point of the dimensions of trust and distrust in unions. Evaluating the subject in terms of employees, professional hotel managers, and union managers who are the stakeholders of the sector is aimed. Per the literature review of the study labor, and employees' obstacles in the tourism industry will be investigated. The status of unionization in the tourism industry will be shown in a summary table, and the preliminary studies on the subject will be discussed. Then, the research methods and the analysis findings of the data obtained from field studies will be addressed.

The main problem of this research is to reveal the perceptions of the employees in tourism, which is a labor-intensive industry, towards the unions that are expected to be their representatives in matters such as wages, personal rights, social rights and job security, especially in working and living conditions. Along with this, it is manifesting and analyzing the approach of employers, managers and unions. As it could be understood from the literature review, there are not many studies on tourism and unions on local literature. The primary aim of this research is to contribute to the literature. Also, to investigate low rate of unionization in Turkish tourism industry, in cause and effect relationship and offer solutions. 


\section{Literature Review}

\subsection{Problems of Labor and Employees in the Tourism Industry}

Many adverse factors such as unqualified workforce, low wages, insufficient employment levels due to seasonality, long working hours are at the eye of the storm of all discussions on working life in the tourism industry. The globalized tourism industry has created mostly unskilled and low-wage employment by spreading to developing countries and, in one sense, increased the exploitation of labor in these countries (Aykaç, 2009: 43) Besides, the widespread unregistered and cheap labor force prevents a qualified workforce from finding a place in the sector (Yorgun, 2013: 58). However, the most critical determinant of quality in tourism is the workforce employed in this industry (İçöz, 1991, Jafari and Sola, 1996, Kızıloğlu and Macit, 2002, Haven-Tang and Jones, 2008).

Since the tourism industry's employment issue is one of the direct determining factors of service quality, it also involves many difficulties. It is quite challenging in tourism enterprises or even impossible to replace the working factor with another production factor, except for a narrow service area (Buyruk, 2014: 387). Those working in the tourism industry confront with many problems such as the intensity of unskilled workers, excessive working hours over legal periods, high turnover rate, unregistered employment, seasonal employment, low wage levels, short seniority, and not being organized (Kaya, 2012, Yorgun, 2013, Buyruk, 2014, Sergeant and Kurr, 2015).

Although many sectors concerning working relations in the tourism industry have similar difficulties, there are also problems specific to tourism. In the final report of the Workshop on Addressing Worker and Employer Relations Problems with Social Dialogue in the Tourism Industry, held in Istanbul in 2017, Öztürk (2018) states these sector-specific problems as follows:

- Low rate of unionization, problems resulting from the authorization process and failure to make sectoral agreements,

- Temporary stay of employees in the sector, not being able to keep trained personnel in the sector, lack of qualified personnel,

- Foreign employment, informal employment, internship employment, temporary employment relationship and employing sub-employer workers,

- Part-time work, on-call work, intermittent work, job security, leisure time, night work, equalization, breastfeeding leave,

- Low wages, insufficient accommodation, unemployment insurance, counting tip as wage,

- There are deficiencies in terms of job security, and the actual service period increase.

\subsection{Unionization in the Tourism Industry}

The change/transformation due to the globalization process and structural changes in unionism first made itself evident by "a significant decrease in unionization rates" (Mahiroğulları, 2012: 12). However, the situation works the other way around. Tourism, which is one of the main actors of the service sector, is fragile due to its structural features. Even if those employed in this sector have union awareness, the sector does not allow unionization (Tekin, 2014: 140). 
Examining unionization in the tourism business world over the USA and some European countries is found to be useful.

Trade unions in the United States are guaranteed organizations by the country's labor law and represent workers in many business lines. The most typical example of professional economic unionism to provide better working conditions for its members without having doctrinal concerns is the United States unionism (Şahin, 2018: 130). Union organization in the USA has been on a declining trend in recent years, as in many countries worldwide. According to the US Bureau of Labor Statistics data, the unionization rate in the country was $10.5 \%$ in 2018 , a 0.2 -point decrease compared to the previous year (BLS, 2019). The trade union sector in which the tourism industry's business lines are gathered in the USA is called the "Leisure and Guest Hospitality" business line. There are" Arts, Entertainment and Recreation," "Accommodation and Food services" business lines under this line of business. There are union organizations in "Accommodation" and "Food services and Drinking places" within the scope of the Accommodation and Food Services business. It is noteworthy that the unionization rate in the food services and beverage places business line, which is estimated to be a part of the tourism industry, is meager, such as $1.3 \%$, according to 2018 data.

There are no single standardized industrial relations systems in the European Union (EU) countries. Regulations and practices in industrial relations are mostly left to the jurisdiction of the member states. However, if it is required to generalize, in that case, the rights regarding union organization in all EU member countries are in line with the norms of the International Labor Organization. However, there are basic structural features peculiar to each country in practice that create a difference between countries, particularly in terms of organizational form, level, rate, number of upper union organizations, and reasons for division, membership structures. Since the existence of a different model in each country in terms of the organization is perhaps the most crucial feature that can be assumed for the EU industrial relations system (Sapancalı, 2007: 4). Overall, unionization rates tend to decline across the EU, except for a few countries. While union density is relatively high, especially in Scandinavian countries, unionization rates are lower in countries in the Mediterranean area. The low unionization rates in these leading Mediterranean countries in tourism are striking. (STATS, 2019).

The World Tourism Organization predicts the growth of the tourism sector exponentially (Bilgiçli, 2021). Tourism is a crucial economic sector in the EU, as in the whole world. European tourism, where most small and medium-sized enterprises are at the forefront, is an essential means of income and employment, mainly for the rural population. While approximately one-third of the world's accommodation activities occur in EU countries, one out of every three people going on touristic trips in the world is a European citizen (Aslan and Akın, 2016: 159 Considering the level of union concentration, the low rate of unionization in business lines related to tourism is also valid for European countries. It creates the widespread use of temporary employment contracts in European countries compared to other sectors (Miguel, 2018).

It can be said that the current situation of the sector has reduced the union organization to low levels in European countries. Britain, Germany, France, and Bulgaria have trade union density of 1-5\%; Latvia, Portugal, Spain, Netherlands, and Austria have a trade union density of $5-15 \%$, and Hungary, Romania, Greece, Malta, Luxembourg, and Norway are countries with a trade union density of $15-30 \%$. Trade union density of more than $30 \%$ is observed in Belgium, Denmark, Slovenia, Cyprus, 
Finland, Sweden, and Italy (Gerogiannis Elias, Kerckhofs Peter, and Vargas Oscar, 2012).

Table 1: Unionization Rates in the Hospitality and Entertainment Business Line (2013-2020)

\begin{tabular}{|c|c|c|c|c|c|}
\hline Year & Period & Unionization Rate(\%) & Year & Period & Unionization Rate (\%) \\
\hline \multirow[b]{2}{*}{2013} & January & 4.4 & \multirow{2}{*}{2017} & January & 3.8 \\
\hline & July & 3.9 & & July & 3.4 \\
\hline \multirow[b]{2}{*}{2014} & January & 4.2 & \multirow{2}{*}{2018} & January & 3.9 \\
\hline & July & 3.6 & & July & 3.4 \\
\hline \multirow[b]{2}{*}{2015} & January & 4.0 & \multirow{2}{*}{2019} & January & 4.2 \\
\hline & July & 3.6 & & July & 3.5 \\
\hline \multirow[b]{2}{*}{2016} & January & 3.9 & \multirow{2}{*}{2020} & January & 3.9 \\
\hline & July & 3.4 & & July & - \\
\hline
\end{tabular}

Table 1 gives the union organization rates between 2013-2020 in the Accommodation and Entertainment Affairs business line No.18.

\subsection{Pioneering Studies on Tourism Trade Unionism}

A limited number of researchers have studied the trade union situation in the Turkish tourism industry. Many studies carried out for different business lines have focused on the gloomy picture of union organization. When studying on union organization in tourism, Yıldırgan (1996) discussed the relationship between job satisfaction and personnel turnover in accommodation businesses by its effect on productivity and tried to measure the impact of unions. Aymankuy (2005) examined the relationship between unionization in tourism and service quality. In a study conducted by Tekin (2014), unionism on the Turkish tourism industry was discussed. Again, in another study carried out by Tekin, Tüfekçi, and Kürşat (2015), the union perception of students receiving tourism education was tried to be measured. Ay (2014) investigated the relationship between national culture, organizational culture, organizational policy perception, and the tendency to be a union member through five-star hotel employees in Istanbul. A study conducted by Yorgun, Keser, and Yılmaz, job, and life satisfaction of union members working in accommodation businesses, was tried to be determined (Yorgun et al. 2008). The following examples can be given to the studies on the subject looking at foreign sources. Chopping investigated the issue of non-unionism in London hotels and restaurants (Chopping, 1977). Mc Far lane (1982) conducted a study on unionism for employers in hotels and restaurants (Mac Far lane, 1982). Besides, Aslan and Wood researched hotel managers about hotel and catering industry unions (Aslan \& Wood, 1993). Piso studied hotel and catering workers in class and unionization (Piso, 1999). In another study, the same researcher examined unionization in the Dublin hotel industry (Piso 2003). Lucas (2009) reviewed low unionization in the British hotel industry under industrial features.

\section{Methodology}

Both qualitative and quantitative methods were applied in the study. The findings obtained from the data were compared, and the results for the differences and relationships were evaluated as a whole. 
The quantitative data of the study were obtained by questionnaire technique. A questionnaire was applied to 805 employees working in four and five-star hotels operating in Istanbul, representing the city hotels and Antalya, representing the summer resorts. In the formation of the survey questions, various scales were used instead of a single scale. The concept of "tourism union" was mainly employed by the researcher in the questions applied. In this study, the attitudes and opinions of tourism workers towards trade unions operating in the tourism business are measured. The questionnaire form used was developed by using the scales used in the studies conducted by Uçkan et al. (2009), Kayıkçı (2013), Urhan and Selamoğlu (2008), Altan et al. (2006), Tekin and Tüfekçi (2015) Uysal and Köse (2014) and taking expert opinions as well.The questions asked to the participants in the semi-structured interview technique in collecting qualitative data are; the managers' and employers' opinion about the low rate of unionization in tourism, whether unions are needed, what are the advantages and disadvantages of unions, their effects on workplace productivity, the possibility of establishing communication between the employer and the union, and the efficiency of unions in tourism.

The qualitative data of the study were obtained using the semi-structured interview technique. Researchers widely prefer semi-structured interviews because they eliminate the limitations in questionnaires, are flexible, and provide in-depth information on a specified subject (Yıldırım \& Şimşek, 2003). The interview form was created with expert opinions and literature review, and a total of eight questions were used, apart from demographic information. The one-sided Anova test was used to examine the differences due to demographic characteristics in the use of quantitative analysis. Tukey post hoc tests were used in order to determine the groups that are the source of the difference in demographic characteristics that were found to be significantly different as a result of the unilateral Anova test.

\subsection{Research Aim}

At least where the leading sectors of the trade union organization in the world and Turkey intensity comes from the tourism sector. Referring specifically to the interests of business scale of Turkey's tourism trade union organization it is known to be extremely low. This study aims to examine the low level of union organization experienced in the tourism industry in the Turkish accommodation sector, through the perceptions of employees' union trust and union insecurity. The research, besides the union perceptions of the sector employees; It handles it with a holistic approach from an employer, manager and trade unionist perspective. Questions below were asked to the participants within the scope of qualitative research:

- How would you interpret the very low rate of unionization in the tourism business in terms of managers and employers?

- Considering today's work conditions, do you think unions are needed?

- What do you think the advantages and disadvantages of unionizing are for a workplace?

- Do you believe that unionized workers will be more productive in the workplace?

- Is it possible to have a positive relationship between the employer and the union? How?

- How do you think the sector capitalists perceive the unions? Why?

-Why does the word "union" seen as a forbidden word in tourism businesses?

- (To hotel managers) During your professional life in tourism sector, have you been in connection with a union? Why? 
- (To union managers) Do you think tourism unions are effective enough in work life in tourism? Why?

Based on the assumption that the research has several dimensions, the research framework aims to create a clear picture by using mixed research methods. In this context, research problems are; the current legislation has emptied the concept of unions, employees have a negative perception about unions due to the current state of the unions, there are negative perceptions of both investors and managers towards unions, the current union managers' determinations about unions, especially the problems in organization and union image, Human Resources (HR) function, which is a result of contemporary management, on de-unionization are a consequence of their practices.

\section{Findings}

Employees working in Turkey's hotel industry constitute the universe where the quantitative data of the research are collected. As of 2019, the accommodation sector employees are 420,721 people (SGK, 2019). The number of tourism workers who are union members over the total number of workers in the sector is seen as 36,927 people. No net number could be reached in determining the total number of employees in Antalya and Istanbul that will form the universe of the research. With the easy sampling method, 805 people working in four and five-star hotels in Istanbul and holiday hotels in Antalya formed the study sample. In cases where the universe's size exceeds 100 thousand, 5\% sampling error, and it should be consisting of 384 samples, at least, that can represent the confidence level of 95\% (Altunışık et al., 2012). Since the required sample size did not change even if the population's size reached 10 million people, the sample number reached in this study was considered sufficient in terms of representation rate.

In this study, restrictive and obstructive factors such as the union issue's sensitivity and the employer's view of the sector as an objectionable concept were influential in choosing the snowball sampling method. Each hotel manager directed another hotel manager who could opinion the union and ensured that the sample was reached in a chain manner.

The quantitative data obtained from the questionnaires were tested with confirmatory factor analysis in the AMOS program. Other analyzes were analyzed in the SPSS program. This research's scale was designed with a total of 32 items with four components: the dimension of trust, socio-economic dimension, union consciousness dimension, and union insecurity dimension. Since the research is quite comprehensive and has a page limitation, only the dimensions of trade union trust and union insecurity are discussed. As a result of the confirmatory factor analysis applied to the scale, it was seen that the factor loads of some expressions were low. Acceptable and perfect fit index values for confirmatory factor analysis, a particular type of structural equation models, are shown in Table 2.Model fit indexes calculated after excluding incompatible items in the scale of union perception and making the necessary modification arrangements are as in Table 2. 
Table 2: Union Perception Scale Confirmatory Factor Analysis Model Fit Indexes

\begin{tabular}{|c|c|c|c|c|}
\hline CMIN/DF & AGFI & GFI & CFI & RMSEA \\
\hline 3,822 & 0,904 & 0,926 & 0,910 & 0,059 \\
\hline
\end{tabular}

When the fit index values in the table are compared with the criterion values, it is seen that AGFI indicates perfect fit, and all other model fit indices except CMIN / DF indicate acceptable fit. CMIN / DF, on the other hand, is a fit index value that tends to show inverse characteristics in the large sample. In this case, when all fit indices are evaluated together, it can be said that the scale is acceptable for the confirmatory factor analysis model.

While the results of the confirmatory factor analysis of the union perception scale are evaluated, it can be assumed that the scale has structural validity with four factors and 21 items. Cronbach's alpha reliability coefficients calculated for the union perception scale and its sub-dimensions, which are structurally validated, are given in Table 3.

Table 3: Union Perception Scale Reliability Statistics

\begin{tabular}{|l|c|c|}
\hline Scale/Sub-dimension & Number of Items & Cronbach's Alpha \\
\hline Security Dimension & $\mathbf{3}$ & $\mathbf{0 . 7 6 9}$ \\
\hline Socio-Economic Dimension & 9 & 0.856 \\
\hline $\begin{array}{l}\text { Union Consciousness } \\
\text { Dimension }\end{array}$ & 3 & 0.539 \\
\hline Union Insecurity Dimension & $\mathbf{6}$ & $\mathbf{0 . 7 4 4}$ \\
\hline
\end{tabular}

Among the techniques used to test the reliability of measurement tools, the Cronbach's $\alpha$ coefficient technique, which was developed by Cronbach (1951), who made the most detailed measurement, indicates the degree of agreement between the questions in the scales with a large number of questions, and takes values between 0 and 1 . When the reliability coefficients in this study are examined, it can be said that the union consciousness sub-dimension is at an acceptable level of security, while the othersub-dimensions are well reliable. Within the research scope, since hotel managers and union executives constituting the working group were selected through snowball sampling, it was elaborately ensured that they consist of people with a specific level of experience in the tourism business life. Interviews with hotel managers and union managers were examined in a thematic framework applying a descriptive analysis method, and the focal points of each theme were addressed.Although there are two items $(0.492-0.497)$ with a contribution of lessthan 0.5 tothescale of the union consciousness, the union consciousness dimension is 0.539 due to the fact that the contributions of these items are close to 0.5 and the confirmatory factor analysis model fit indices of the scale are at an acceptable level. It has been decided to leave the item of 'in the scale. 
Findings Regarding the Perceptions of Hotel Employees

Table 4: Demographic Characteristics $(n=805)$

\begin{tabular}{|c|c|c|c|c|c|}
\hline Variable & $\mathbf{n}$ & $\%$ & Variable & $\mathbf{n}$ & $\%$ \\
\hline $\begin{array}{l}\text { Age } \\
17 \text { years and under } \\
18-25 \\
26-32 \\
33-39 \\
40-46 \\
47 \text { years and older }\end{array}$ & $\begin{array}{l}3 \\
96 \\
223 \\
239 \\
201 \\
43\end{array}$ & $\begin{array}{l}0.4 \\
11.9 \\
27.7 \\
29.7 \\
25.0 \\
5.3\end{array}$ & $\begin{array}{l}\text { Education } \\
\text { Primary School } \\
\text { Secondary School } \\
\text { High School } \\
\text { Associate Degree } \\
\text { Bachelor's Degree } \\
\text { Postgraduate }\end{array}$ & $\begin{array}{l}51 \\
93 \\
430 \\
69 \\
153 \\
9\end{array}$ & $\begin{array}{l}6.3 \\
11.6 \\
53.4 \\
8.6 \\
19.0 \\
1.1\end{array}$ \\
\hline $\begin{array}{l}\text { Gender } \\
\text { Female } \\
\text { Male }\end{array}$ & $\begin{array}{l}361 \\
444\end{array}$ & $\begin{array}{l}44.8 \\
55.2\end{array}$ & $\begin{array}{l}\text { City of Occupation } \\
\text { Antalya } \\
\text { Istanbul }\end{array}$ & $\begin{array}{l}400 \\
405\end{array}$ & $\begin{array}{l}49.7 \\
50.3\end{array}$ \\
\hline $\begin{array}{l}\text { Monthly Income (TL) } \\
\text { Minimum Wage } \\
\text { Minimum wage-2,000 } \\
2,001-3,000 \\
3,001-4,000 \\
4,001-5,000 \\
\text { 5,001 and above } \\
\text { No response }\end{array}$ & $\begin{array}{l}42 \\
227 \\
277 \\
111 \\
60 \\
36 \\
52\end{array}$ & $\begin{array}{l}5.2 \\
28.2 \\
34.4 \\
13.8 \\
7.5 \\
4.5 \\
6.5\end{array}$ & $\begin{array}{l}\text { Sectoral Experience } \\
\text { Less than } 1 \text { year } \\
1-3 \text { years } \\
4-6 \text { years } \\
7-9 \text { years } \\
10-12 \text { years } \\
13 \text { years and over }\end{array}$ & $\begin{array}{l}39 \\
141 \\
206 \\
203 \\
75 \\
141\end{array}$ & $\begin{array}{l}4.8 \\
17.5 \\
25.6 \\
25.2 \\
9.3 \\
17.5\end{array}$ \\
\hline $\begin{array}{l}\text { Duration of Work } \\
\text { Less than } 1 \text { year } \\
1-3 \text { years } \\
4-6 \text { years } \\
7-9 \text { years } \\
10-12 \text { years } \\
13 \text { years and over }\end{array}$ & $\begin{array}{l}144 \\
313 \\
231 \\
63 \\
21 \\
33\end{array}$ & $\begin{array}{l}17.9 \\
38.9 \\
28.7 \\
7.8 \\
2.6 \\
4.1\end{array}$ & $\begin{array}{l}\text { Department Food } \\
\text { Beverage } \\
\text { Front Desk } \\
\text { Housekeeping } \\
\text { Kitchen } \\
\text { Safety } \\
\text { Valet } \\
\text { Animation } \\
\text { Technical Service } \\
\text { Other } \\
\text { No response }\end{array}$ & $\begin{array}{l}201 \\
135 \\
144 \\
204 \\
43 \\
18 \\
9 \\
16 \\
23 \\
12\end{array}$ & $\begin{array}{l}24.9 \\
16.8 \\
17.9 \\
25.3 \\
5.3 \\
2.2 \\
1.1 \\
2.0 \\
2.9 \\
1.5\end{array}$ \\
\hline $\begin{array}{l}\text { Marital Status } \\
\text { Married } \\
\text { Single } \\
\text { Divorced }\end{array}$ & $\begin{array}{l}510 \\
262 \\
33\end{array}$ & $\begin{array}{l}63.4 \\
32.5 \\
4.1\end{array}$ & $\begin{array}{l}\text { The Star of the Hotel } \\
4 \text { stars } \\
5 \text { stars }\end{array}$ & $\begin{array}{l}54 \\
751\end{array}$ & $\begin{array}{l}6.7 \\
93.3\end{array}$ \\
\hline
\end{tabular}

\subsection{Findings Regarding Unionization}

The first three reasons shown by the participants in the first period for not being a member of the tourism union are as follows; $14.99 \%$ "Lack of an organized union at work," $12.26 \%$ "does not want to pay dues," $12.26 \%$ "Think that my situation will not change even if I am a member." 
Table 5: The Reasons for Not Being a Member of the Tourism Union

\begin{tabular}{|c|c|c|c|c|c|c|}
\hline \multirow[t]{2}{*}{$\begin{array}{l}\text { Reasons for Not Being a Member of the } \\
\text { Tourism Union }\end{array}$} & \multicolumn{2}{|c|}{$\begin{array}{c}\text { Important } \\
1\end{array}$} & \multicolumn{2}{|c|}{ Important 2} & \multicolumn{2}{|c|}{$\begin{array}{c}\text { Important } \\
3\end{array}$} \\
\hline & $\mathbf{n}$ & $\%$ & $\mathbf{n}$ & $\%$ & $\mathbf{n}$ & $\%$ \\
\hline 1 I don't trust unions & 81 & 11.04 & 33 & 4.56 & 37 & 5.17 \\
\hline 2 I don't trust trade unionists & 67 & 9.13 & 112 & 15.47 & 118 & 16.50 \\
\hline 3 My employers solve my problems. & 86 & 11.72 & 90 & 12.43 & 99 & 13.85 \\
\hline 4There is no organized union in my workplace. & 110 & 14.99 & 108 & 14.92 & 88 & 12.31 \\
\hline $5 \mathrm{I}$ do not want to pay dues. & 90 & 12.26 & 108 & 14.92 & 88 & 12.31 \\
\hline 6 I think the unions have ideological pressure & 57 & 7.77 & 56 & 7.73 & 27 & 3.78 \\
\hline 7 My coworkers are not members. & 94 & 12.81 & 79 & 10.91 & 82 & 11.47 \\
\hline $\begin{array}{l}8 \text { I think my situation will not change even } \\
\text { though I am a member. }\end{array}$ & 90 & 12.26 & 87 & 12.02 & 94 & 13.15 \\
\hline 9 Trade unions do not meet my expectations. & 43 & 5.86 & 42 & 5.80 & 55 & 7.69 \\
\hline 10 Employer pressure. & 6 & 0.82 & 9 & 1.24 & 25 & 3.50 \\
\hline 11 Other & 10 & 1.36 & 0 & 0.00 & 2 & 0.28 \\
\hline
\end{tabular}

The first three reasons shown by the participants in the first period of being a member of the tourism union are as follows; $30.36 \%$ "Because it protects my economic and personal rights," 16.07\% "Because I have an intellectual affinity," 16.07\% "Because it is a strong union" and $16.7 \%$ "To feel safe."

\section{Table 6: Significance Degrees of the Reasons for Being a Member of the Tourism Union}

\begin{tabular}{|l|c|c|c|c|c|c|}
\hline Reasons for Being a Member of the Tourism & \multicolumn{2}{|c|}{$\begin{array}{l}\text { Important } \\
\text { Union }\end{array}$} & \multicolumn{2}{|c|}{$\begin{array}{l}\text { Important } \\
\mathbf{2}\end{array}$} & \multicolumn{2}{|c|}{$\begin{array}{l}\text { Important } \\
\mathbf{3}\end{array}$} \\
\cline { 2 - 8 } & $\mathbf{n}$ & $\%$ & $\mathbf{n}$ & $\%$ & $\mathbf{n}$ & $\%$ \\
\hline $\begin{array}{l}\text { 1 Because it protects my economic and } \\
\text { personal rights }\end{array}$ & 17 & 30.36 & 6 & 12.00 & 6 & 11.32 \\
\hline 2 For my intellectual affinity & 9 & 16.07 & 0 & 0.00 & 3 & 5.66 \\
\hline 3 For being a strong union & 9 & 16.07 & 13 & 26.00 & 0 & 0.00 \\
\hline $\begin{array}{l}\text { 4 To prevent administrative pressure from } \\
\text { affecting my business life }\end{array}$ & 6 & 10.71 & 16 & 32.00 & 0 & 0.00 \\
\hline 5 To provide unity & 6 & 10.71 & 12 & 24.00 & 6 & 11.32 \\
\hline 6 Because I like their actions and activities. & 0 & 0.00 & 0 & 0.00 & 23 & 43.40 \\
\hline 7 To feel safe & 9 & 16.07 & 3 & 6.00 & 15 & 28.30 \\
\hline 8 Other & 0 & 0.00 & 0 & 0.00 & 0 & 0.00 \\
\hline
\end{tabular}


Table 7: Ranking of Actors Behind Tourism Employees Not/Can Not Being Unionized

\begin{tabular}{|l|c|c|c|c|c|c|}
\hline \multirow{2}{*}{$\begin{array}{l}\text { Ranking of the importance of the } \\
\text { actors behind the non-unionization } \\
\text { of tourism workers }\end{array}$} & \multicolumn{2}{|c|}{ Important 1 } & \multicolumn{2}{|c|}{ Important 2 } & \multicolumn{2}{c|}{ Important 3 } \\
\cline { 2 - 7 } & $\mathbf{n}$ & $\%$ & $\mathbf{n}$ & $\%$ & $\mathbf{n}$ & $\%$ \\
\hline 1 Boss & 313 & 39.37 & 109 & 13.73 & 97 & 12.36 \\
\hline 2 Manager & 102 & 12.83 & 274 & 34.51 & 109 & 13.89 \\
\hline 3 Employees themselves & 147 & 18.49 & 210 & 26.45 & 211 & 26.88 \\
\hline 4 Union & 111 & 13.96 & 126 & 15.87 & 168 & 21.40 \\
\hline 5 Legal Structure & 120 & 15.09 & 75 & 9.45 & 200 & 25.48 \\
\hline 6 Other & 2 & 0.25 & 0 & 0.00 & 0 & 0.00 \\
\hline
\end{tabular}

The first important reason behind the fact that tourism workers are not unionized is as follows: $39.37 \%$ boss, $18.49 \%$ employees themselves, $15.09 \%$ legal structure, $13.96 \%$ union.

Table 8: Descriptive Statistics of the Union Perception Scale

\begin{tabular}{|l|c|c|c|c|c|}
\hline Variable & $\mathbf{n}$ & Minimum & Maximum & Mean & Standard Deviation \\
\hline Security Dimension & $\mathbf{8 0 5}$ & $\mathbf{1 . 0 0}$ & $\mathbf{5 . 0 0}$ & $\mathbf{3 . 1 5 8 2}$ & $\mathbf{1 . 1 4 0 9 0}$ \\
\hline Socio-Economic Dimension & 805 & 1.00 & 5.00 & 3.0065 & 0.85963 \\
\hline Union Consciousness Dimension & 805 & 1.00 & 5.00 & 3.0683 & 0.90993 \\
\hline Union Insecurity Dimension & $\mathbf{8 0 5}$ & $\mathbf{1 . 0 0}$ & $\mathbf{5 . 0 0}$ & $\mathbf{3 . 0 8 3 9}$ & $\mathbf{0 . 8 3 3 7 3}$ \\
\hline
\end{tabular}

The security dimension has a minimum of 1 , maximum of 5 , average of 3.15 , and 1.14 as standard deviation values. The union insecurity dimension has a minimum of 1 , maximum of 5 , average of 3.08 , and 0.83 of standard deviation values.

\subsection{Analyses}

\section{Diversity Analysis of the Union Perception Scale}

An independent sample T-test was applied to investigate the mean differences due to demographic characteristics with two options. The one-sided ANOVA test was applied to analyze the differences based on demographic features with more than two options. Tukey post hoc tests were applied to determine the groups that are the source of the difference in demographic characteristics, which were significantly different from the unilateral ANOVA test.

When Table 9 is examined, it is seen that the only statistically significant difference is among the participants in the 40 to 46 age group and the participants among the ages of 18 and 25 . The trade union trust levels of the participants between the ages of 40 and 46 were higher than those between the ages of 18 and 25 . 
Table 9: Union Perception Sub-Dimensions by Age Variable ANOVA Test Statistics

\begin{tabular}{|c|c|c|c|c|c|c|}
\hline Variable & Age Group & $\mathbf{n}$ & Mean & Standard Deviation & $\mathbf{F}$ & Sig. \\
\hline \multirow{7}{*}{$\begin{array}{l}\text { Security } \\
\text { Dimension }\end{array}$} & 17 years and under & 3 & 2.5556 & 0.83887 & \multirow{7}{*}{2.729} & \multirow{7}{*}{$0.019^{*}$} \\
\hline & $18-25$ & 96 & 2.8160 & 0.97916 & & \\
\hline & $26-32$ & 223 & 3.1928 & 1.09471 & & \\
\hline & $33-39$ & 239 & 3.1283 & 1.14548 & & \\
\hline & $40-46$ & 201 & 3.2985 & 1.21947 & & \\
\hline & 47 and above & 43 & 3.2946 & 1.20231 & & \\
\hline & Total & 805 & 3.1582 & 1.14090 & & \\
\hline \multirow{7}{*}{$\begin{array}{l}\text { Union } \\
\text { Insecurity } \\
\text { Dimension }\end{array}$} & 17 years and under & 3 & 3.0556 & 0.09623 & \multirow{7}{*}{3.392} & \multirow{7}{*}{$0.005^{\star}$} \\
\hline & $18-25$ & 96 & 2.9410 & 0.80676 & & \\
\hline & $26-32$ & 223 & 3.0359 & 0.88402 & & \\
\hline & 33-39 & 239 & 3.0056 & 0.83121 & & \\
\hline & $40-46$ & 201 & 3.2562 & 0.77853 & & \\
\hline & 47 and above & 43 & 3.2829 & 0.79060 & & \\
\hline & Total & 805 & 3.0839 & 0.83373 & & \\
\hline
\end{tabular}

* Symbolizes statistical significance at a 95\% confidence level.

Independent sample t-test statistics for testing the differences between female and male participants in terms of union perception scale sub-dimensions are shown in Table 10 below.

Tablo 10: Union Perception Sub-Dimensions Independent Sample T-Test Statistics by Gender Variable

\begin{tabular}{|c|c|c|c|c|c|c|}
\hline Variable & Gender & $n$ & Average & $\begin{array}{l}\text { Standard } \\
\text { Deviation }\end{array}$ & $\mathbf{t}$ & sig. \\
\hline \multirow{2}{*}{$\begin{array}{l}\text { Security } \\
\text { Dimension }\end{array}$} & Man & 444 & 3,1126 & 1,09829 & \multirow[b]{2}{*}{1.257} & \multirow[b]{2}{*}{0,21} \\
\hline & Woman & 361 & 3,2142 & 1,19036 & & \\
\hline \multirow{2}{*}{$\begin{array}{l}\text { Socio-Economic } \\
\text { Dimension }\end{array}$} & Man & 444 & 3,0230 & 0,83451 & \multirow{2}{*}{0,61} & \multirow{2}{*}{0,55} \\
\hline & Woman & 361 & 2,9861 & 0,89030 & & \\
\hline \multirow{2}{*}{$\begin{array}{l}\text { Union Awareness } \\
\text { Dimension }\end{array}$} & Man & 444 & 3,0683 & 0,89789 & \multirow{2}{*}{0,00} & \multirow{2}{*}{1,00} \\
\hline & Woman & 361 & 3,0683 & 0,92577 & & \\
\hline \multirow{2}{*}{$\begin{array}{l}\text { Union Insecurity } \\
\text { Dimension }\end{array}$} & Man & 444 & 3,0957 & 0,79748 & \multirow{2}{*}{0,45} & \multirow{2}{*}{0,65} \\
\hline & Woman & 361 & 3,0693 & 0,87717 & & \\
\hline
\end{tabular}

When Table 10 is examined, it is seen that the significance values of the independent sample t-test calculated for all sub-dimensions are above 0.05 . In this case, it can be said that there is no statistically significant difference between female and male participants in terms of security dimension, socio-economic dimension, union consciousness dimension and union trust dimension at $95 \%$ confidence level (sig.> 0.05 ). 
Table 11: Trade Union Perception Sub-Dimensions by Income Level ANOVA Test Statistics

\begin{tabular}{|c|c|c|c|c|c|c|}
\hline Variable & Income Level & $\mathbf{N}$ & Mean & $\begin{array}{l}\text { Standard } \\
\text { Deviation }\end{array}$ & $\mathbf{F}$ & Sig. \\
\hline \multirow{8}{*}{$\begin{array}{l}\text { Security } \\
\text { Dimension }\end{array}$} & Minimum Wages & 42 & 2.7460 & 0.88287 & \multirow{8}{*}{3.605} & \multirow{8}{*}{$0.002^{*}$} \\
\hline & Minimum wage - between 2,500 TL & 227 & 3.0764 & 1.06386 & & \\
\hline & $2,501-3,000$ & 277 & 3.0842 & 1.10887 & & \\
\hline & $3,001-4,000$ & 111 & 3.5195 & 1.22407 & & \\
\hline & $4,001-5,000$ & 60 & 3.3278 & 1.14896 & & \\
\hline & 5,001 and above & 36 & 3.3426 & 1.42425 & & \\
\hline & No answer & 52 & 3.1474 & 1.23742 & & \\
\hline & Total & 805 & 3.1582 & 1.14090 & & \\
\hline \multirow{8}{*}{$\begin{array}{l}\text { Union } \\
\text { Insecurity } \\
\text { Dimension }\end{array}$} & Minimum Wages & 42 & 2.7381 & 0.78099 & \multirow{8}{*}{3.657} & \multirow{8}{*}{$0.001^{\prime}$} \\
\hline & Minimum wage - between 2,500 TL & 227 & 3.0308 & 0.73541 & & \\
\hline & $2,501-3,000$ & 277 & 3.0307 & 0.84602 & & \\
\hline & $3,001-4,000$ & 111 & 3.1817 & 0.86356 & & \\
\hline & $4,001-5,000$ & 60 & 3.1889 & 0.93804 & & \\
\hline & 5,001 and above & 36 & 3.4120 & 0.71546 & & \\
\hline & No answer & 52 & 3.3205 & 0.96273 & & \\
\hline & Total & 805 & 3.0839 & 0.83373 & & \\
\hline
\end{tabular}

* Symbolizes statistical significance at a 95\% confidence level.

In this case, there were statistically significant differences at a $95 \%$ confidence level in terms of the security dimension and the dimension of union insecurity among the participants with various income levels (Sig.<0.05).

Table 12: Union Perception Sub-Dimensions by Working Time in Tourism Industry ANOVA Test Statistics

\begin{tabular}{|c|c|c|c|c|c|c|}
\hline Variable & $\begin{array}{l}\text { Tourism Industry } \\
\text { Experience }\end{array}$ & $\mathbf{n}$ & Mean & Standard Deviation & $\mathbf{F}$ & Sig. \\
\hline \multirow{7}{*}{$\begin{array}{l}\text { Security } \\
\text { Dimension }\end{array}$} & Less than 1 year & 39 & 2.8376 & 0.94551 & \multirow{7}{*}{3.540} & \multirow{7}{*}{$0.004^{*}$} \\
\hline & $1-3$ years & 141 & 2.9905 & 1.07714 & & \\
\hline & 4-6 years & 206 & 3.1133 & 1.08656 & & \\
\hline & $7-9$ years & 203 & 3.1199 & 1.13954 & & \\
\hline & $10-12$ years & 75 & 3.4933 & 1.32357 & & \\
\hline & 13 years and above & 141 & 3.3570 & 1.17558 & & \\
\hline & Total & 805 & 3.1582 & 1.14090 & & \\
\hline \multirow{7}{*}{$\begin{array}{l}\text { Union } \\
\text { Insecurity } \\
\text { Dimension }\end{array}$} & Less than 1 year & 39 & 2.9060 & 0.83228 & \multirow{7}{*}{4.426} & \multirow{7}{*}{$0.001^{*}$} \\
\hline & $1-3$ years & 141 & 2.9515 & 0.88204 & & \\
\hline & 4-6 years & 206 & 2.9968 & 0.77196 & & \\
\hline & $7-9$ years & 203 & 3.0722 & 0.86808 & & \\
\hline & $10-12$ years & 75 & 3.2822 & 0.76816 & & \\
\hline & 13 years and above & 141 & 3.3038 & 0.80408 & & \\
\hline & Total & 805 & 3.0839 & 0.83373 & & \\
\hline
\end{tabular}

* Symbolizes statistical significance at a 95\% confidence level.

Participants who have worked in the tourism industry for 10 to 12 years have a higher level of union security than those who have worked in the tourism industry for 
less than one year and those who have been in the tourism industry for one to three years. Participants with 13 years and more experience in the tourism industry have a higher level of union insecurity than participants with one to three years of tourism industry experience and four to six years of tourism industry experience. In this case, it can be assumed that the distrust towards the unions increases accordingly as the professional experience in the sector increases. In a study measuring union perceptions of university students by Tekin and Tüfekçi (2015), it is stated that $36 \%$ of the youth has a positive view of the union. Still, it is doubtful that their trust in the union will remain at this level when they get started in the working life.

Independent sample t-test statistics for testing the differences between the participants who work in Antalya and Istanbul hotels in terms of union perception scale sub-dimensions are shown in Table 13.

\section{Tablo 13: Union Perception Sub-Dimensions Independent Sample T-Test Statistics by City Variable}

\begin{tabular}{|c|c|c|c|c|c|c|}
\hline Variable & Province & $\mathbf{n}$ & Average & $\begin{array}{l}\text { Standard } \\
\text { Deviation }\end{array}$ & $\mathbf{t}$ & sig. \\
\hline \multirow{2}{*}{$\begin{array}{l}\text { Security } \\
\text { Dimension }\end{array}$} & Antalya & 400 & 3,1908 & 1,21348 & \multirow{2}{*}{$\begin{array}{c}0,80 \\
7\end{array}$} & \multirow{2}{*}{0,420} \\
\hline & İstanbul & 405 & 3,1259 & 1,06489 & & \\
\hline \multirow{2}{*}{$\begin{array}{l}\text { Socio-Economic } \\
\text { Dimension }\end{array}$} & Antalya & 400 & 3,0097 & 0,89831 & \multirow{2}{*}{$\begin{array}{c}0,10 \\
6\end{array}$} & \multirow{2}{*}{0,916} \\
\hline & İstanbul & 405 & 3,0033 & 0,82075 & & \\
\hline \multirow{2}{*}{$\begin{array}{l}\text { Union } \\
\text { Awareness } \\
\text { Dimension }\end{array}$} & Antalya & 400 & 3,0875 & 0,93977 & \multirow{2}{*}{$\begin{array}{c}0,59 \\
4\end{array}$} & \multirow[b]{2}{*}{0,553} \\
\hline & İstanbul & 405 & 3,0494 & 0,88022 & & \\
\hline \multirow{2}{*}{$\begin{array}{l}\text { Union Insecurity } \\
\text { Dimension }\end{array}$} & Antalya & 400 & 3,1058 & 0,88832 & \multirow{2}{*}{$\begin{array}{c}0,74 \\
3\end{array}$} & \multirow{2}{*}{0,458} \\
\hline & İstanbul & 405 & 3,0621 & 0,77656 & & \\
\hline
\end{tabular}

When Table 13 is examined, it is seen that the significance values of the independent sample t-test calculated for all sub-dimensions are above 0.05 . In this case, it can be said that there is no statistically significant difference at the $95 \%$ confidence level between the participants working in Antalya and Istanbul hotels in terms of security dimension, socio-economic dimension, union awareness dimension and union trust dimension (Sig.> 0.05).

Independent sample t-test statistics for testing the differences between the participants who work in four starand five star hotels in terms of union perception scalesub-dimensions are shown in Table 14. When Table 14 is examined, it is seen that the significance values of the independent sample t-test calculated for all subdimensions are above 0.05 . In this case, it can be said that there is no statistically significant difference at the $95 \%$ confidence level between the participants working in four star and five star hotels in terms of security dimension, socio-economic dimension, union awareness dimension and union trust dimension. (Sig.> 0.05) 
Tablo 14: Union Perception Sub-Dimensions Independent Sample T-Test Statistics by the Class of the Hotel

\begin{tabular}{|c|c|c|c|c|c|c|}
\hline Variable & $\begin{array}{l}\text { Hotel } \\
\text { Class }\end{array}$ & $\mathbf{N}$ & Average & $\begin{array}{l}\text { Standard } \\
\text { Deviation }\end{array}$ & $t$ & sig. \\
\hline \multirow{2}{*}{$\begin{array}{l}\text { Security } \\
\text { Dimension }\end{array}$} & Four Stars & 54 & 3,2654 & 1,16982 & \multirow{2}{*}{0.715} & \multirow{2}{*}{0.475} \\
\hline & Five Stars & 751 & 3,1505 & 1,13920 & & \\
\hline \multirow{2}{*}{$\begin{array}{l}\text { Socio-Economic } \\
\text { Dimension }\end{array}$} & Four Stars & 54 & 3,0967 & 0,94701 & \multirow{2}{*}{0.798} & \multirow{2}{*}{0.425} \\
\hline & Five Stars & 751 & 3,0000 & 0,85333 & & \\
\hline \multirow{2}{*}{$\begin{array}{l}\text { Union } \\
\text { Awareness } \\
\text { Dimension }\end{array}$} & Four Stars & 54 & 3,1420 & 0,96175 & \multirow[b]{2}{*}{0.616} & \multirow[b]{2}{*}{0.538} \\
\hline & Five Stars & 751 & 3,0630 & 0,90653 & & \\
\hline \multirow{2}{*}{$\begin{array}{l}\text { Union Insecurity } \\
\text { Dimension }\end{array}$} & Four Stars & 54 & 3,1605 & 0,85043 & \multirow{2}{*}{0.699} & \multirow{2}{*}{0.485} \\
\hline & Five Stars & 751 & 3,0783 & 0,83282 & & \\
\hline
\end{tabular}

Table 15: Correlation Analysis Between Dimensions of the Union Perception Scale

\begin{tabular}{|c|c|c|c|c|}
\hline & $\begin{array}{l}\text { Security } \\
\text { Dimension }\end{array}$ & $\begin{array}{c}\text { Socio- } \\
\text { Economic } \\
\text { Dimension }\end{array}$ & $\begin{array}{c}\text { Union } \\
\text { Consciousness } \\
\text { Dimension }\end{array}$ & $\begin{array}{c}\text { Union } \\
\text { Insecurity } \\
\text { Dimension } \\
\end{array}$ \\
\hline \multirow{3}{*}{ Security Dimension } & 1 & & & \\
\hline & & & & \\
\hline & 805 & & & \\
\hline \multirow{3}{*}{$\begin{array}{l}\text { Socio-Economic } \\
\text { Dimension }\end{array}$} & $0.676^{* *}$ & 1 & & \\
\hline & 0.000 & & & \\
\hline & 805 & 805 & & \\
\hline \multirow{3}{*}{$\begin{array}{l}\text { Union } \\
\text { Consciousness } \\
\text { Dimension } \\
\end{array}$} & $0.513^{* *}$ & $0.640^{* *}$ & 1 & \\
\hline & 0.000 & 0.000 & & \\
\hline & 805 & 805 & 805 & \\
\hline \multirow{3}{*}{$\begin{array}{l}\text { Union Insecurity } \\
\text { Dimension }\end{array}$} & $0.427^{\star \star}$ & $0.461^{* *}$ & $0.459^{* *}$ & 1 \\
\hline & 0.000 & 0.000 & 0.000 & \\
\hline & 805 & 805 & 805 & 805 \\
\hline
\end{tabular}

As shown in the table, correlation relations between all dimensions are statistically significant and positive at a $99 \%$ confidence level. There was no strong or weak correlation between dimensions. All correlational relationships are between strong and weak. The highest correlation coefficient is defined between the socioeconomic dimension and the security dimension positively in the same direction and with a coefficient of 0.676 . In other words, while the socio-economic dimension increases, the security dimension also increases. The lowest correlation relationship is between union insecurity and security.

\section{Findings Regarding the Views of Hotel and Union Managers}

The interviews conducted with hotel managers and union managers were examined in a thematic framework using descriptive analysis method, and focal points of each theme were discussed. When the reliability coefficients in this study are examined, it can be said that the union consciousness sub-dimension is at an acceptable level of security, while the other sub-dimensions are well reliable. 


\section{Findings Regarding the Views of Hotel Managers}

Ten hotel managers in Antalya and 8 in Istanbul were interviewed face-to-face, over the phone, and electronically. Each interview was recorded using a note-taking method, as the participants rejected the request for audio recording during the interviews. Hotel managers/employers participating in the interviews were coded as OY1, OY2, OY3...OY18. The opinions of hotel managers on trade union trust-oriented questions are listed below as a whole.

Managers believe that the low level of union organization in the tourism business is due to the sector, employees, and unions' specific conditions. In addition to sectoral reasons such as the seasonality of tourism, the industry being a challenging business line, and the high turnover of the labor force; the reasons arising from the employees such as the intense unskilled workforce, the insufficient awareness of the unions of the employees, not trusting the unions and unionists, thinking that union membership will cause them difficulties in the workplace are put forward. Besides, it is thought that unions have excessive political and ideological labels, the inability of union managers to instill union awareness in new generation employees, destructive competition among unions, and yellow union practices cause the business world and society to remain distant at unions.

Hotel managers and employers believe that tourism workers needed a union in the previous years, but today workers can solve all their problems by communicating them to the management. If the unions develop projects to support the sector, both employee's and employers' level of requirement for the union will increase. Still, most of the managers interviewed do not deny the contribution of the trade unions in improving the working conditions in the sector. Yet, to establish this positive relationship, unions should improve their current understanding and revise themselves according to age and tourism conditions.

\section{Advantages of trade unions;}

- Unconscious personnel will be made aware of claiming their rights.

- Workers will work more motivated and self-consciously.

- By making the worker-employer relationship more formal, the win-win principle will be put in practice.

- Work peace will be provided in the workplace.

- There is a risk of disruption to services in the workplace by actions such as strikes and slowdowns.

- A worker who lolls against the union may tend to work without discipline.

- There may be dissociation and polarization among the employees arising from the distinction between unionized and non-unionized.

- The union is an element that increases costs in the workplace.

Hotel managers agree that this matter depends on the unions' approach in establishing a peaceful relationship among unions and employers. It seems exceptionally possible to build such a positive relationship if today's tourism unions avoid the classical unionist perspective and adopt an appropriate approach to the sector's working conditions.

According to hotel managers' general view, capitalists operating in the tourism industry are organizations whose unions try to share in their earnings. Consequently, there is a negative perception of unions in the eyes of capital owners. The union is 
mostly a banned word since there is a concern that it will disrupt the established order in most workplaces.

It is a known fact that the concept of union is almost a banned word in tourism enterprises. Hotel managers interviewed on this issue frame the reasons why the union is regarded as such.

- A union deranges the system in the workplace.

- The union establishes the ground for dissociation, grouping, and division among employees.

- As long as the union holds a trump card like a strike, it is met with the employer's resistance.

- The union is a factor that increases costs.

\section{Findings Regarding the Views of Union Managers}

A face-to-face interview was carried with a union manager in Antalya and one union expert academician, and one union manager in Istanbul. One union manager in Ankara, electronically, represented the worker segment. Each interview lasted an average of one hour. The union executives' views concerning the questions focused on trade union trust are listed below as a whole.

According to the union managers' views, it is possible to summarize the reasons for the low level of union in the sector as the reasons arising from employees, employers, and managers, and unions. Accordingly, the workers may change their jobs frequently, it is a branch of work where mostly young people work, and the organizational awareness had disappeared after September 12. It is estimated that employers exert intense pressure on employees about unions, that union managers cannot instill union awareness in the new generation, there is a destructive union competition, and that incompetent persons negatively affect the image of unions by engaging in unionism.

According to all union managers, unions are obligated. Since the current Human Resources system is built on legitimizing employer decisions, it does not have a dispute resolution method. Under these conditions, the union has no alternative in solving the obstacles of the workers. Since our country's working and living conditions are getting harder in this line of business, unions are necessitated.

According to the union executives questioned, the advantages of a union to a workplace surpass its disadvantages. Accordingly;

Union advantages: unions increase the quality and efficiency of the workplace. Unions serve to increase employees' work and life satisfaction, which increases efficiency and peace in the workplace. The system is guaranteed in the workplace; unity and solidarity are strengthened. Thanks to the union, employees adopt and own the workplace more and see themselves as their homeowners. Labor turnover drops. Labor costs are easy to calculate. The disadvantages of the union are that personnel costs rise. Union organizing can lead to conflict. There may be situations such as strikes that the industry will find challenging.

According to the union executives interviewed, it seems impossible to establish a positive relationship under the current conditions. Both sides should stop regarding the other as the enemy. Relationships can grow as long as the parties remain within their borders. Examples of such positive relationships with some organized workplaces can be observed. 
According to union executives, capital owners consider the union to be their adversary. Since they believe they will lose their influence on the worker due to the union. They perceive union membership as a rebellion against the order in the workplace. They view the union as an obstacle to the decisions to be taken in the workplace.

\section{Conclusion and Suggestions}

The main results obtained from the literature and field findings of this study, which investigated the perception of trade union trust in Turkey's accommodation sector, are as follows;

- Low unionization in the accommodation sector in Turkey remains. It is believed that reasons such as the sector's specific working conditions, seasonality feature, the weight of the young workforce in employment, and the high turnover of the labor force complicate for the employees to organize unions.

- Many workers in the sector believe that there will be no change in their position or social rights when they become union members. Still, they will lose their jobs and be blacklisted in the labor market. In many interviews, it is stated that a hotel worker who has been in some way connected with a union in the past would have a bad record, and it would be challenging to find a job again in hotels. Consequently, it is possible to assume that the unions' concept is regarded as a banned word in the lodging industry. A low level of unionization in the accommodation sector is also due to intense employer pressure Because the number of employers who behave negatively enough to almost ban the word union in the business they own is undeniably high.

- Hotel managers and employers believe that the workers' productivity would decrease in the workplace if there is a union and that the employees who rely on the union would start abusing the workplace. Such an approach negatively affects the view of the employers of the sector towards the union. Besides, there are also ideas claiming that the opposite situation is encountered in hotel management where there is a union organization, that is, a unionized worker is more connected to his/her job and workplace, works more enthusiastically and efficiently, and starts to see oneself as a member of that family.

Some solution suggestions specific to the stakeholders can be offered for the problems revealed as a result of the research;

- Tourism unions should focus primarily on efforts to eliminate the problem of trust with workers, employers, and the general public. It is imperative to end the perception in people's minds that "union means an act of terrorism" since it is impossible to establish healthy relationships with specific groups without social support and trust. It is thought that the unions' image before the public should be improved first.

- Trade unions should provide guidance and counseling to every worker working in the sector, whether they are members or not. Today, many workers who do not know how to seek their rights and do not know what to do when they are unfairly dismissed experience victimization. Many tourism workers quit their jobs at the end of the season. However, many do not know how to get their rights, such as compensation, notice, and unemployment benefits. At this 
point, unions will contribute to strengthening their existing social image, as it is essential in terms of supporting, guiding, guiding, providing legal support when necessary, promoting themselves regardless of their political views, race, religion, language, and union affiliations.

- Trade unions are non-governmental organizations that should be in contact with all stakeholders of the sector. In this context, the relationships they will establish with universities that provide tourism education will contribute to the management of young people's perceptions about unions and improve their awareness level while still at school. Necessary conditions should be provided for tourism students to do their internships in tourism unions, and the importance of organized labor should be included in the course curriculum.

- Professional hotel managers should explain the contributions of the union to the workplace well to employers and the idea that the union is not an enemy. Still, the idea of being one of the stakeholders in the business life should be adopted. It is not an acceptable situation that employers prevent union membership, which is the worker's constitutional right. It should not be overlooked that the employers' anti-union attitudes and the pressure they have placed on the worker should be eliminated or at least softened.

- The specific working conditions of tourism often affect workers negatively. Everyone accepts that many unemployed workers by the end of the season are in a difficult situation. Standard solutions to be developed by employers with unions to solve this problem can give new impetus to both workers and employer-union relations. The allowance to be created by the employers to be used in the period of unemployment and the fund to be formed from some of the membership fees of the unions can be a solution for the difficult times of the workers.

- Tourism workers need to take a more active and decisive attitude in solving problems and create an element of pressure on employers. At this point, it should not be forgotten that trade unions can create a binding element and an organized power. Everyone criticizes existing unions and union understanding, and the unions and unionists are shown as the reason for non-unionism. Yet, it is the workers themselves who will improve this situation. The fact that they express their criticism of the union structure in our country more, and even take part in the unions and continue their struggle here may cause the ongoing union understanding to change gradually.

- Every worker, unionized or not, should claim their rights by using the power provided by law. At this point, the union is an actor that provides the opportunity for organized struggle. In this respect, being a union member would give strength to the tourism worker.

- Hotel businesses with a union organization can be registered similar to the blue flag application with "worker-friendly," "labor-friendly." 


\section{References}

Aile, Çalışma ve Sosyal Hizmetler Bakanlığı, (2019). ailevecalisma.gov.tr/calismahayati-istatistikleri/sendikal-istatistikler/isci-sendikalari-istatistikleri, E.T. 16 Şubat 2019.

Altan, Z. Kağnıcıoğlu, D. Şişman, Y. and Sungur, Z. (2006). İşçi Profili Araştırması: Eskişehir Örneği. Eskişehir Osmangazi Üniversitesi Sosyal Bilimler Dergisi, 7(2).

Aslan, A. and Wood, R. (1993). Trade Unions in The Hotel and Catering Industry: The Views of Hotel Manager. Employe Relations, 15(2), ss.61-70.

Aslan, S. and Akın, G. (2016). Avrupa Birliği'nin Turizm Politikası Çerçevesinde Yapısal Fonların Değerlendirilmesi. Akademik Bakış Dergisi(55), ss.158-172.

Ay, D. A. (2014). Ulusal Kültür, Örgür Kültürü, Örgütsel Politika Algısı ve Sendika Üyesi Olma Eğilimi İlişkisi, Balıkesir Üniversitesi SBE, Turizm İşletmeciliği ABD, Yayınlanmamış Doktora Tezi. Balıkesir.

Aykaç, A. (2009). Yeni İşler, Yeni İşçiler Turizm Sektöründe Emek (1 b.). Iletişim Yayınları İstanbul.

Aymankuy, Ş. (2005), Turizm Sektöründe Sendikalaşma Ve Hizmet Kalitesi İlişkisi. Yayınlanmamış Doktora Tezi, Balıkesir Üniversitesi SBE.

Baumgartner, H. and Homburg, C. (1996). Applications of structural equation modeling in marketing and consumer research: A reviev. International Journal of Research in Marketing, 13(2), ss. 139-161.

Bentler, P. M. and Bonett, D.G.(1980). Significance tests and goodness of fit in the analysis of covariance structures. Psychological Bulletin, ss.588-606.

Bilgiçli, İ. (2021). The Effect of Vacation on Employers and Managers in Terms of the Perception of Motivation Tools: Sakarya Case, Iktisadi, Sosyal ve Kültürel yönleriyle Turizm, Gazi Kitabevi, Ankara. Isbn:978-625-7315-80-7, ss.133-158

Bureau of Labour Statistics (2019). https://www.bls.gov/news.release/union2.nro.htm. E.T. 27 Ocak 2019.

Browne, M. W and Cudeck, R. (1993). Alternative ways of assessing model fit. In K. A. Bollen and J. S. Long (Eds.), Testing structural equation models. Newbury Park, CA: Sage., ss.136-162.

Buyruk, L. (2014). Turizm İşletmelerinde Kariyer Engelleri. N. Ş. Şule A. Tükeltürk içinde, Turizm İşletmelerinde Çalışan Ilişkileri Yönetimi (s. 387-403). Ankara: Detay Yayıncılık.

Chopping, B. (1977). Unionisation in London Hotels and Restaurants. England: Hertford College, University of Oxford.

Çavuş, Ö. H. and Kurar, İ. (2015). Turizm Sektöründe Çalışanların Hukuki Haklarına İlişkin Farkındalıkları: Konaklama ve Yiyecek İçecek İşletmeleri Çalışanları Üzerine Bir Araştırma, Dokuz Eylül Üniversitesi Sosyal Bilimler Enstitüsü Dergisi C:17, S.2, ss.147-174.

Eurofound, (2019). Industrial Relations Representativeness of the European social partner organisations: Hotels, restaurants and cafe (HORECA) sector, Research Report, https://www.eurofound.europa.eu/tr:https://www.eurofound.europa.eu/publication s/report/2018/representativeness-of-the-european-social-partner-organisationshotels restaurants-and-cafe-horeca, E.T. 16 Şubat 2019.

Giannis Elias, Kerkofs, P. Vargas, O.(2012). Employment and Industrial Relations in the Hotels and Restaurants sector.European Foundation for the Improvement of Living and Working Conditions. https://www.eurofound.europa.eu/publications/report/E.T. 20 Nisan 2018.

Haven-Tang, C. and Jones, E. (2008). Labour Market and Skills Needs of the Tourism and Related Sectors in Wales. International Journal of Tourism Research, 10: ss.353-363. 
İçöz, O. (1991). Turizm Sektörünün Gelişmesinde İnsan Unsurunun Önemi. Anatolia: Turizm Araştırmaları Dergisi, 2(6), ss.15-18.

Jafari, J. and Sola, F. E. (1996). Human Resources Development and Quality Tourism: A Multi-Conference Report, Annals of Tourism Research, C: 23, No: 1, ss. 228231.

Kaya, İ. (2012). Türk Turizm Sektöründe İstihdamın Temel Özelliklerinin ve Sorunlarının Ücretli Çalışanlar Açısından Coğrafi Bölgelere Göre Analizi. Balıkesir Üniversitesi Sosyal Bilimler Enstitüsü Dergisi, 15(28), ss.241-257.

Kayıkçı, K. (2013). Türkiye'de Kamu ve Eğitim Alanında Sendikalaşma ve Öğretmen ile Okul Yöneticilerinin Sendikalardan Beklentileri. Amme ldaresi Dergisi, ss.99126.

Kızıloğlu, T. and Macit, M. (2002). Turizm Yöneticilerinde Kendini Geliştirme, Turizm Eğitimi Konferans-Workshop, 11-13 Aralık, Ankara.

Kline, R. (2011). Principles and Practice of Structural Equation Modeling. New York: Guilford Press.

Kocabaş, F. (2004). Endüstri İlişkilerinde Dönüşüm, http://dergipark.gov.tr/dpusbe/issue/

4752/65281, E.T. 12 Eylül 2018.

Lucas, R. (2009). Is Low Unionisation In The British Hospitality Industry Due To Industry Characteristics. International Journal of Hospitality Management, 28, 42-52.

Mac Far Lane, A. (1982). Trade Unionismand the Employer in hotels and Restaurants. International Journal of Hospitality Management, 1(1), ss.35-43.

Mahiroğulları, A. (2012). XXI. Yüzyıla Girerken Sendikacılık: Günümüzdeki Değişim, Dönüşüm ve Gelecek İçin Arayışlar. Hak-Iş Uluslararası emek ve Toplum

Miguel, P. S. (2018). www.eurofound.europa.eu, E.T. Şubat 13, 2019.

Öztürk, M. O. (2018). Turizm Sektöründe İşçi ve İşveren İlişkileri Sorunların Sosyal Diyalog ile Ele Alınması Çalıştayı. Çalıştay Sonuç Raporu, İstanbul.

Piso, A. (1999). Hotel and catering workers: class and unionisation. Employe Relations, 21(2), ss. 176-178.

Piso, A. (2003). Unionisation In The Dublin Hotel Industry. International Journal of Tourism Research, 5, 211-224.

Sapancalı, F. (2007). Avrupa Birliği'ne Üye Ülkelerde Sendikal Örgütlenme, Sorunlar ve Yeni Stratejiler, https://www.ceis.org.tr/dergiDocs/makale127.pdf, E.T. 18 Şubat 2018.

Schermelleh, E. K. Mossbrugger, H. and Hans, M. (2003). Evaluating the Fit of Structural Equation Models: Tests of signifiance and Descriptive goodness-of-Fit Measures. Methods of Psyicologiacal Research Online, 8(2), ss.23-74.

Stats, (2019). www.stats.oecd.org, https://stats.oecd.org/. E.T. 11 Şubat 2019.

Şahin, N. (2018). Ülke Karşılaştırmaları Işığında Türkiye'de Sendika-Siyaset İlişkisinin Değerlendirilmesi. Fırat Üniversitesi lïBF Uluslararası İktisadi ve Idari Bilimler Dergisi, 2(1), 115-143.

Tekin, Ö. A. (2014). Sendikacılık ve Türkiye Turizm Sektörü. (125-152, Dü.) Süleyman Demirel Üniversitesi Sosyal bilimler Enstitüsü Dergisi(20)., 1(1), ss.9-33.

Tekin, Ö. A. and Tüfekçi, Ö. K. (2015). 'Turizm Öğrencilerinin Sendika Algısı: Üniversite Öğrencileri Üzerine Bir Araştırma'. Afyon Kocatepe Üniversitesi Sosyal Bilimler Dergisi, 17(1), 171-200.

Tüzünkan, D. (2015).nDüzgün İş'in Hedefleri Açısından Türk Turizm Sektörünün Genel Özellikleri. Selçuk üniversitesi lïBF Sosyal Ve akademik Araştırmalar Dergisi.(29), ss.241-251.

Uçkan, B. and Kağnıcıoğlu, D. (2009). İşçilerin Sendikalara İlişkin Algı Ve Tutumları: Eskişehir Örneği. Çalışma Ve Toplum Dergisi(3), ss.35-56. 
Urhan, B. Veselamoğlu, A. (2008). İşçilerin sendikalara Yönelik Tutum ve Davranışları: Kocaeli Örneği. Çalışma ve toplum Dergisi, ss.171-197.

Uysal, Ş. and Köse, S. (2014). Kamu Görevlilerinin Sendika Faaliyetlerine Bakışı Üzerine Manisa İlinde Bir Araştırma. CBÜ Sosyal Bilimler Dergisi, 12(2), ss.99124.

Yıldırgan, R. (1996). Konaklama İşletmelerinde Verimlilik Kapsamında İş DoyumuPersonel Devri İlintisi ve Sendikalar. Dokuz Eylül Üniversitesi SBE Turizm İşletmeciliği Anabilim Dalı Yayınlanmamış Yüksek Lisans Tezi.

Yıldırım, A. and Şimşek, H. (2013). Sosyal Bilimlerde Nitel Araştırma Yöntemleri. Ankara: Seçkin Yayınları.

Yorgun, S. (2013). Türkiye'de Turizm Sektöründe Esnek İstihdam uygulamaları ve Toplu İş Sözleşmelerinde Yer alan düzenlemeler. Turizm ve Araştırma Dergisi, ss.53-72

Yorgun, S. K. (2008). Konaklama İşletmelerinde Çalışan Sendika Üyelerinin İş ve Yaşam Doyumunu Belirlemeye Yönelik Bir alan Araştırması. İstanbul 